\title{
The Effect of Recruitment and Training on Commitment and Performance of Village Business Entity (Bumdes) Management in Kampar Regency Riau Province
}

\section{Novianti Zalukhu*, Susi Hendriani, \& Kurniawaty Fitri}

Faculty of Economics and Business, Universitas Riau, Pekanbaru, Indonesia

* zalukhunovianti@gmail.com

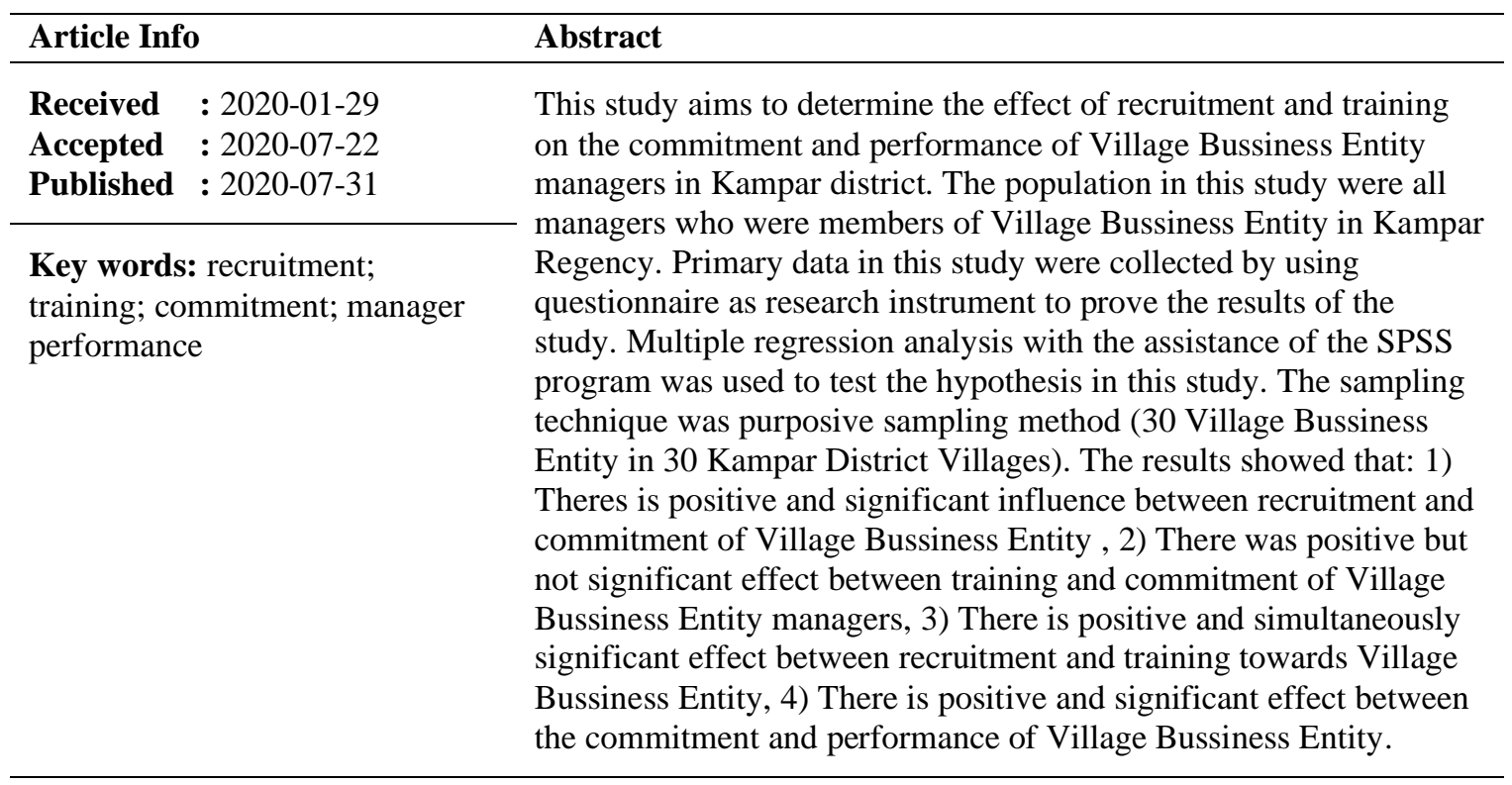

\section{INTRODUCTION}

Indonesian is a country with it's highly abundant natural resources. Especially natural resources are in the village so needed development and the empowerment to manage it, so that can be a source of income for the village. The village often considered a very lagging far from the development of urban area, so that in 2014-2019 Indonesian's President make a NAWACITA programme with the goalof build areas left especially in the village to be able and compete and is excepted to have a income with the urban areas.

One of the problems being faced in the distribution of development at present is the difference in the progress of development between rural and urban areas. The village is the basis of a strong national community system and is able to develop a political, cultural and economic system.Efforts that can be made to strengthen regions and villages are through optimizing village potential, both in natural resources and human resources. One thing that can be done in this effort is by increasing the creativity of rural communities in utilizing natural resources in the area so that it can be an opportunity to improve welfare and economic change. The government provides great support so that the village has a business entity that is able to develop and drive the local economy. This is as stated in Law Number 32 of 2004 concerning Regional Government (Harun \& Herlina, 2017).

The existence of a Village-Owned Enterprise (BUMDES) is expected to be able to drive and develop the economy in the village and surrounding villages. Village Bussiness Entity or BUMDES is one of the programs of NAWACITA activities made by the President of the Republic of Indonesia which aims to advance villages so that their development is equivalent to cities, so that villages do not become disadvantaged areas and can continue to show their existence. 
Village Bussiness Entity or BUMDES is a business entity that is managed by the community and village government in an effort to strengthen the village economy which is formed based on the needs and potential of the village. In addition, Village Bussiness Entity also acts as a driver of the rural economy and has a very important function for the community's economy.

It is known that the condition of the villages in Kampar Regency, Riau Province currently has Village Bussiness Entity managers who have not carried out their duties and responsibilities properly, thus making some business entities that have been run tend to be undeveloped and even stagnant. Based on Kampar Regency Regulation Number 14 of 2007 concerning the establishment of Village Owned Enterprises (BUMDES) in Kampar Regency (Kampar Regency Regional Gazette of 2007 Number 14), one way to achieve economic growth in rural areas is through the growth of micro village institutions where one of one micro institution in a rural area is a Village-Owned Enterprise (BUMDES).

The main problem that is often faced by BUMDES is in terms of the quality of the performance of its human resources, especially managers. The performance of human resources will determine the competitive advantage of a business entity or company (Mangkunegara, 2012), so there are several factors that need to be considered in managing human resources in an organization or business entity.

Human resource management starts from the initial stage, namely recruitment activities. Recruitment is one of the determining factors in the success of human resource performance. Quality human resources are generally born through a quality recruitment process (Bangun, 2012). Good prospective employees generally also come from the right recruitment process so that the next business entity will obtain qualified, committed and competent human resources. The business entity itself must have the requirements in the job analysis in accordance with the regulations that have been applied. This is as stated in the Regulation of the Minister of Villages Number 4 of 2015 article 14, namely the requirements to become a BUMDES operational operator which includes:

a. Village Communities who have an entrepreneurial passion

b. Domiciled and settled in the village for at least 2 (two) years

c. Good personality, honest, fair, capable, and attention to the economic efforts of the villaged. Minimum level of education is Senior High School/ Madrasah Aliyah / Vocational Schools or equivalent.

If the recruitment process is done correctly and the prospective human resources can meet the requirements as stated in the Regulation of the Minister of the Village, then they are expected to provide optimal performance.The selection of Village Bussiness Entity administrators in Kampar Regency is carried out by the village community through village deliberations in accordance with the provisions in the Ministerial Regulation concerning Rules of Procedure and Mechanisms for Village Deliberation Decision Making (Permendes Number 4 of 2015 Article 16).

Another factor that might affect the performance of human resources at Village Bussiness Entity is training. Village Bussiness Entity managers in carrying out their duties and functions must have various skills that can be obtained through training. The training included entrepreneurship skills, communication, negotiation and mastery of information technology. These skills will then be used to support management in several business fields owned by Village Bussiness Entity so that in the future it is expected to improve the village economy. Entrepreneurship is a field of science that has developed over the years and is interesting to develop (Hisrich in Slamet, 2014) Hisrich also revealed that individuals who study entrepreneurship will have as much as 3 to 4 times more desires in starting their businesses. Through human resource training, they will have knowledge and abilities that are reliable in their fields (Handoko in Verra, 2013). 
In addition to recruitment and training, another factor influencing human resource performance is organizational commitment. Mathis and Jackson in Sopiah (2010) define organizational commitment as the degree to which employees believe and accept organizational goals and will remain or will not leave the organization. If the commitment of the employee is high towards the work he is undertaking, of course this will greatly affect his performance.

Commitment in improving the performance of BUMDES managers is very important, where managers can accept the goals of the organization and implement them based on their duties and functions. So, this is the research question :

1. Does recruitment affect the commitment of Village Bussiness Entity

2. Does the training affect the commitment of Village Bussiness Entity managers?

3. Does recruitment and training affect the commitment of Village Bussiness Entity managers?

4. Does commitment affect the performance of Village Bussiness Entity managers?

\section{Problem Statement}

1. Does recruitment affect the commitment of Village Bussiness Entity

2. Does the training affect the commitment of Village Bussiness Entity managers?

3. Does recruitment and training affect the commitment of Village Bussiness Entity managers?

4. Does commitment affect the performance of Village Bussiness Entity managers

\section{LITERATURE REVIEW}

\section{Recruitment}

According to Bangun (2012), recruitment is the process of finding prospective employees who meet the requirements in the number, quality and type needed, both in the short, medium, and long term. The indicators used in recruitment according to Hasibuan (2010) are:

1. Basic Recruitment

2. Recruitment Sources

3. Recruitment Method

\section{Training}

According to Widodo (2015) training is a series of individual and employee activities with the aim of systematically increasing expertise and knowledge so as to be able to have professional performance in their fields. Indicators used in training according to are:

1. Skills

2. Responsibility

3. Expertise

4. Achieving job satisfaction.

\section{Commitment}

According to Gibson et al (2014), commitment is a feeling of identification, engagement, and loyalty expressed by workers in each company. The dimensions of commitment according to Robbins (2015) are as follows:

1. Affective Commitments

2. Normative Commitment

3. Continuous Commitment

Indicators of commitment according to Robbins are as follows:

1. Loyalty

2. Willingness

3. Pride.

\section{Performance}

According to Wibowo (2015) Performance is the implementation of the plans that have been prepared. Implementation of performance is carried out by human resources who have the 
ability, competence, motivation and interests. The indicators of performance according to Mangkunegara (2012) are as follows:

1. Attitude

2. Honesty

3. Responsibilities

4. Discipline

5. Reliability

6. Loyalty

7. Cooperation

\section{RESEARCH FRAMEWORK}

a. Recruitment is one of the important things for the company to seek new employment, so for new employment they should have a commitment for join the company. If they not have a good commitment for company they can't give the best perfomance for the company.

b. Training is an activity which the company is trying to develop the skill and ability of they employees to grow up and have more knowledge. In this case means the training is also useful so that employees are more commited to keep working and they can give the best perfomance on the company

c. Recruitment and training both of them have an influence on employee commitment (Rivai, 2014) and the precess of them be able to help the employee decides to join or not to the company.

Commitment is a strong desire of emloyees to remain within organization and strive to proide the best for the company (Meyer and Allen in Robbins, 2015). In that case it can be concluded if employees have a high commitment to give the best effort for the company.

Based on the explanation, author make a research method like this figure:

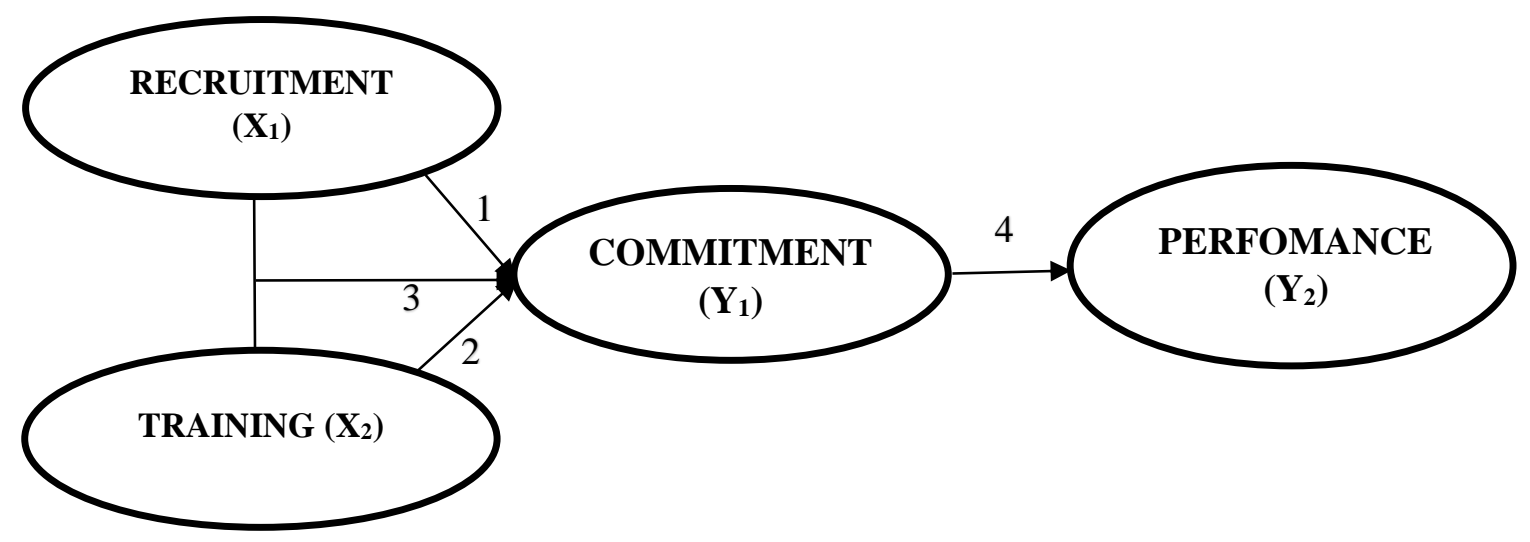

Source: Indrayanto (2012), Jatmiko (2015), and Ariyanti (2018)

Figure 1. Research Method

\section{RESEARCH HYPOTHESIS}

Based on the problem statement and the research framework above, the research hypothesis can be formulated as follows:

1) It is suspected that recruitment significantly influences the commitment of BUMDES Managers.

2) It is suspected that training significantly influences the commitment of BUMDES Managers.

3) It is suspected that simultaneous recruitment and training affect the commitment of BUMDES Managers.

4) It is suspected that the commitment significantly influences the performance of BUMDES managers. 


\section{RESEARCH METHODS}

\section{Research sites}

This research was conducted in Kampar Regency, Riau Province.

\section{Population and Sample}

The population in this study was the managers of 30 BUMDES in Kampar District, Riau Province. The criteria for determining the population is Village Owned Entre Prises which has been established and developing since the last 3 years.

\section{Data collection technique}

Data collection techniques used in this study are:

a. Interview

b. Observation

c. Questionnaire. On this technique, author use a Likert Scale like this table:

Table 1. Indicator of Recruitment

\begin{tabular}{|c|c|c|c|c|c|c|c|c|c|}
\hline \multicolumn{10}{|c|}{ Respondents' Responses } \\
\hline No & Indicator's Question & VA & A & $\mathrm{N}$ & $\mathrm{D}$ & VD & Total & Average & Explanation \\
\hline \multirow[t]{4}{*}{1} & Village-Owned & & & & & & & & \\
\hline & Enterprises have a & & & & & & & & \\
\hline & $\begin{array}{l}\text { recruitment basis and } \\
\text { have carried out }\end{array}$ & 28 & 0 & 0 & 0 & 2 & & & \\
\hline & $\begin{array}{l}\text { recruitment in accordance } \\
\text { with applicable } \\
\text { regulations. }\end{array}$ & 140 & 0 & 0 & 0 & 2 & 142 & 4,73 & Very Good \\
\hline \multirow[t]{2}{*}{2} & $\begin{array}{l}\text { To fill vacant positions at } \\
\text { Village-Owned }\end{array}$ & 3 & 15 & 9 & 0 & 3 & & & \\
\hline & $\begin{array}{l}\text { Enterprises, internal } \\
\text { recruitment is often done. }\end{array}$ & 15 & 60 & 27 & 0 & 3 & 105 & 3,50 & Good \\
\hline \multirow[t]{5}{*}{3} & The recruitment of & & & & & & & & \\
\hline & Village-Owned & 4 & 5 & 2 & 8 & 11 & & & \\
\hline & $\begin{array}{l}\text { Enterprises managers is } \\
\text { often carried out in } \\
\text { private }\end{array}$ & 20 & 20 & 6 & 16 & 11 & 73 & 2,43 & Not Good \\
\hline & \multirow{2}{*}{ Average } & 35 & 20 & 11 & 8 & 16 & 90 & & \\
\hline & & 175 & 80 & 33 & 16 & 16 & 320 & 3,55 & Good \\
\hline
\end{tabular}

Source: Research Result in, 2020

Table 2. Indicator of Training

\begin{tabular}{llcccccccc}
\hline \multirow{2}{*}{ No } & \multirow{2}{*}{ Indicator's Question } & \multicolumn{9}{c}{ Respondents' Responses } & \multicolumn{2}{c}{ Average } \\
\cline { 2 - 10 } & & VA & A & N & D & VD & Total & Average & Explanation \\
\hline 1 & After attending the & 12 & 6 & 11 & 1 & 0 & & & \\
& $\begin{array}{l}\text { training, I became more } \\
\text { skilled at work. }\end{array}$ & 60 & 24 & 33 & 2 & 0 & 119 & 3,96 & Good \\
\hline 2 & Training makes me more & 17 & 12 & 1 & 0 & 0 & & & \\
& responsible for work. & 85 & 60 & 3 & 0 & 0 & 148 & 4,93 & Very Good \\
\hline 3 & Training makes me have & 1 & 26 & 0 & 0 & 3 & & & \\
& a specialskills. & 5 & 104 & 0 & 0 & 3 & 112 & 3,73 & Good \\
\hline 4 & Training gives & 2 & 25 & 1 & 1 & 1 & & & \\
& satisfaction at work. & 10 & 100 & 3 & 2 & 1 & 116 & 3,86 & Good \\
\hline \multirow{2}{*}{} & Average & 30 & 69 & 13 & 2 & 4 & 118 & & \\
& 160 & 288 & 39 & 4 & 4 & 495 & 4,19 & Very Good \\
\hline
\end{tabular}

Source: Research Result in, 2020 
Table 3. Indicator of Commitment

\begin{tabular}{|c|c|c|c|c|c|c|c|c|c|}
\hline \multirow{2}{*}{ No } & \multirow{2}{*}{ Indicator's Question } & \multicolumn{5}{|c|}{ Respondents' Responses } & \multicolumn{3}{|c|}{ Average } \\
\hline & & VA & A & $\mathrm{N}$ & $\mathrm{D}$ & VD & Total & Average & Explanation \\
\hline \multirow[t]{2}{*}{1} & $\begin{array}{l}\text { I have a commitment to } \\
\text { develop the Village }\end{array}$ & 5 & 25 & 0 & 0 & 0 & & & \\
\hline & $\begin{array}{l}\text { Owned Enterprises } \\
\text { continuously. }\end{array}$ & 25 & 100 & 0 & 0 & 0 & 125 & 4,16 & Very Good \\
\hline \multirow[t]{2}{*}{2} & $\begin{array}{l}\text { I am committed to } \\
\text { managing a Village- }\end{array}$ & 6 & 23 & 1 & 0 & 0 & & & \\
\hline & $\begin{array}{l}\text { Owned Enterprise as long } \\
\text { as it is entrusted. }\end{array}$ & 30 & 92 & 3 & 0 & 0 & 122 & 4,06 & Very Good \\
\hline \multirow[t]{4}{*}{3} & I am proud to be part of a & 8 & 21 & 1 & 0 & 0 & & & \\
\hline & Village-Owned Enterprise. & 40 & 84 & 3 & 0 & 0 & 127 & 4,23 & Very Good \\
\hline & \multirow{2}{*}{ Average } & 19 & 69 & 2 & 0 & 0 & 90 & 4,18 & Very Good \\
\hline & & 95 & 276 & 6 & & & 377 & & \\
\hline
\end{tabular}

Source: Research Result in, 2020

Table 4. Indicator of Perfomance

\begin{tabular}{|c|c|c|c|c|c|c|c|c|c|}
\hline \multirow{2}{*}{ No } & \multirow{2}{*}{ Indicator's Question } & \multicolumn{5}{|c|}{ Respondents' Responses } & \multicolumn{3}{|c|}{ Average } \\
\hline & & VA & $\mathrm{A}$ & $\mathrm{N}$ & $\mathrm{D}$ & VD & Total & Average & Explanation \\
\hline \multirow[t]{2}{*}{1} & $\begin{array}{l}\text { I can work together with } \\
\text { various parties in } \\
\text { managing the Village }\end{array}$ & 7 & 19 & 1 & 0 & 3 & & & \\
\hline & Owned Enterprises. & 35 & 76 & 3 & 0 & 3 & 117 & 3,90 & Good \\
\hline \multirow[t]{2}{*}{2} & $\begin{array}{l}\text { My participation has had } \\
\text { an impact on }\end{array}$ & 4 & 24 & 2 & 0 & 0 & & & \\
\hline & $\begin{array}{l}\text { community-managed } \\
\text { businesses }\end{array}$ & 20 & 96 & 6 & 0 & 0 & 122 & 4,06 & Very Good \\
\hline \multirow[t]{2}{*}{3} & $\begin{array}{l}\text { I have been very } \\
\text { transparent in managing }\end{array}$ & 3 & 23 & 0 & 1 & 1 & & & \\
\hline & $\begin{array}{l}\text { village-owned } \\
\text { enterprises }\end{array}$ & 15 & 92 & 0 & 2 & 1 & 110 & 3,66 & Good \\
\hline \multirow[t]{4}{*}{4} & $\begin{array}{l}\text { I am always responsible } \\
\text { for what is entrusted in } \\
\text { the management of }\end{array}$ & 4 & 24 & 0 & 1 & 1 & & & \\
\hline & $\begin{array}{l}\text { Village-Owned } \\
\text { Enterprises. }\end{array}$ & 20 & 96 & 0 & 2 & 1 & 119 & 3,96 & Good \\
\hline & \multirow{2}{*}{ Average } & 18 & 90 & 3 & 2 & 5 & 118 & & \\
\hline & & 90 & 360 & 9 & 4 & 5 & 468 & 3,96 & Good \\
\hline
\end{tabular}

Source: Research Result in, 2020

\section{DATA ANALYSIS TECHNIQUE}

\section{Validity Test}

Table 5. Validity Test Result

\begin{tabular}{lcccc}
\hline Variable & Indicator & r Count Results & r Table & Explanation \\
\hline & $\mathrm{Y}_{2 \_1}$ & 0.846 & 0.361 & Valid \\
Manager Performance $\left(\mathrm{Y}_{2}\right)$ & $\mathrm{Y}_{2 \_}$ & 0.811 & 0.361 & Valid \\
& $\mathrm{Y}_{2 \_3}$ & 0.884 & 0.361 & Valid \\
& $\mathrm{Y}_{2 \_}$ & 0.511 & 0.361 & Valid \\
\hline \multirow{2}{*}{ Commitment $\left(\mathrm{Y}_{1}\right)$} & $\mathrm{Y}_{1 \_1}$ & 0.831 & 0.361 & Valid \\
& $\mathrm{Y}_{1 \_2}$ & 0.927 & 0.361 & Valid \\
& $\mathrm{Y}_{1 \_3}$ & 0.953 & 0.361 & Valid \\
\hline Recruitment $\left(\mathrm{X}_{1}\right)$ & $\mathrm{X}_{1 \_1}$ & 0.446 & 0.361 & Valid \\
\hline
\end{tabular}




\begin{tabular}{lcccc}
\hline Variable & Indicator & r Count Results & r Table & Explanation \\
\hline & $\mathrm{X}_{1 \_2}$ & 0.628 & 0.361 & Valid \\
& $\mathrm{X}_{1 \_3}$ & 0.637 & 0.361 & Valid \\
\hline \multirow{4}{*}{ Training $\left(\mathrm{X}_{2}\right)$} & $\mathrm{X}_{2 \_1}$ & 0.424 & 0.361 & Valid \\
& $\mathrm{X}_{2 \_2}$ & 0.564 & 0.361 & Valid \\
\cline { 2 - 5 } & $\mathrm{X}_{2 \_3}$ & 0.441 & 0.361 & Valid \\
& $\mathrm{X}_{2 \_4}$ & 0.649 & 0.361 & Valid \\
\hline
\end{tabular}

Source: Research Result in, 2020

From Table 5, it can be seen that from the correlation test conducted, it is known that all questions raised in the questionnaire are valid because the value of $r$ count is more than the value of $r$ table, which is a value of 0.05 .

\section{Reliability Test}

Table 6. Reliability Test Results

\begin{tabular}{clccc}
\hline NO & Variable & Cronbach's Alpha & Limit Value & Explanation \\
\hline 1 & Recruitment & 0,949 & 0,6 & Reliabel \\
2 & Training & 0,752 & 0,6 & Reliabel \\
3 & Commitment & 0,888 & 0,6 & Reliabel \\
4 & Manager Performance & 0,719 & 0,6 & Reliabel \\
\hline Source $:$ Research Result in, 2020 & & &
\end{tabular}

From Table 6 it can be seen that the reliability value of all variables is> 0.6 which means that all measuring instruments used in this study are reliable or trustworthy.

\section{Determination Coefficient Test (R2)}

Table 7. Stage 1 of $\mathrm{R}^{2}$ Test Results

Model Summary

\begin{tabular}{ccccc}
\hline Model & $\mathrm{R}$ & R Square & Adjusted R Square & Std. Error of the Estimate \\
\hline 1 & $.484^{\mathrm{a}}$ & .235 & .178 & 1.10876 \\
\hline
\end{tabular}

Dependent Variable: commitment

Predictors: (Constant), training, recruitment

Source: Research Result in, 2020

From Table 7, it can be seen that the coefficient of determination (R2) obtained is equal to 0.235 . The meaning is that the percentage of recruitment and training influence on the commitment of managers is $23.5 \%$, while the remaining $76.5 \%$ is influenced by other variables not included in this test.

Table 8. Stage 2 of R2 Test Results

\section{Model Summary}

\begin{tabular}{ccccc}
\hline Model & $\mathrm{R}$ & R Square & Adjusted R Square & Std. Error of the Estimate \\
\hline 1 & $.440^{\mathrm{a}}$ & .194 & .165 & 2.17182 \\
\hline
\end{tabular}

a. Predictors: (Constant), commitment

b. Dependent Variable: performance

Source: Research Result in, 2020

From Table 8, a coefficient of determination (R2) of 0.194 is obtained. This result indicates that the percentage of commitment influence on the performance of BUMDES 
managers is $19 \%$, while the remaining $81 \%$ is influenced by other variables not included in this test.

\section{Simultaneous Test (F Test)}

Table 9. Simultaneous Test Results (F Test)

\begin{tabular}{llrrrrr}
\multicolumn{7}{c}{ ANOVA $^{\mathrm{a}}$} \\
\multicolumn{1}{l}{ Model } & \multicolumn{2}{c}{ Sum of Squares } & df & Mean Square & \multicolumn{1}{c}{ F } & \multicolumn{1}{c}{ Sig. } \\
\hline $1 \quad$ Regression & 10.174 & 2 & 5.087 & 4.138 & $.027^{\mathrm{b}}$ \\
& Residual & 33.193 & 27 & 1.229 & & \\
& Total & 43.367 & 29 & & & \\
\hline
\end{tabular}

a. Dependent Variable: commitment

b. Predictors: (Constant), training, recruitment

Source: Research Result in, 2020

From Table 9 it can be seen that the value of $\mathrm{F}$ count obtained is 4.138 with a significance of 0.02 . Obtained $\mathrm{F}$ table at $5 \%$ alpha with the equation $\mathrm{n}-\mathrm{k}-1 ; \mathrm{k}=30-2-1 ; 2=27$; $2=3.354$, where $\mathrm{n}$ is the number of samples, $\mathrm{k}$ is the number of independent variables and 1 is constant. In addition, it is known that the F count is $(4,138)>$ F table $(3,354)$ or Sig. $(0.027)$ $<$ alpha (0.05). Thus, it can be concluded that the proposed hypothesis was accepted which indicates that the recruitment and training variables together influence the commitment.

\section{Partial Test (t test)}

Table 10. Stage 1 Partial Test Results (t Test)

Coefficients $^{\mathrm{a}}$

\begin{tabular}{|c|c|c|c|c|c|}
\hline \multirow[b]{2}{*}{ Model } & \multicolumn{2}{|c|}{ Unstandardized Coefficients } & \multirow{2}{*}{$\begin{array}{l}\text { Standardized Coefficients } \\
\text { Beta }\end{array}$} & \multirow[b]{2}{*}{$\mathrm{T}$} & \multirow[b]{2}{*}{ Sig. } \\
\hline & B & Std. Error & & & \\
\hline (Constant) & 2.441 & 1.098 & & 2.223 & .035 \\
\hline Recruitment & .190 & .139 & 286 & 1.368 & .018 \\
\hline Training & .204 & .167 & .256 & 1.225 & .231 \\
\hline
\end{tabular}

a. Dependent Variable: Commitment

Source: Research Result in, 2020

From table 10 it can be seen that the regression equation of step 1 is as follows:

$\mathrm{Y} 1=\mathrm{a}+\mathrm{b}_{1} \mathrm{X}_{1}+\mathrm{b}_{2} \mathrm{X}_{2+} \mathrm{e}$

$\mathrm{Y} 1=1+0,286 \mathrm{X}_{1}+0,256 \mathrm{X}_{2}+\mathrm{e}_{1}$

$\mathrm{e}_{1}=\sqrt{1-R^{2}}=\sqrt{1-0,235^{2}}=0,944$

The description of the above equation is as follows:

1. The coefficient of the recruitment stage variable is 0.286 . These results indicate that each increase in perception of recruitment by one unit, it will increase commitment by 0.286 units and vice versa, assuming a fixed variable.

2. The coefficient of the training stage variable is 0.256 . These results indicate that each increase in perception of training by one unit, commitment will increase by 0.256 units and vice versa, assuming the other variables are fixed.

3. The coefficient of error obtained is 0.944 units. Then from Table 6, partial test results are also obtained by looking at $t$ arithmetic. Meanwhile, the $t$ table values at the 5\% (2-tailed) significance level were obtained by the k-1 equation; alpha / $2=30-2-1 ; 0.05 / 2=27 ; 0.025$ $=2.052$, where $\mathrm{n}$ is the number of samples, $\mathrm{k}$ is the number of independent variables and 1 is constant. Thus the following decisions are obtained:

a. Recruitment. It was obtained that $t$ value $(1.368)<t$ table $(2.052)$ or Sig. $(0.018)<$ alpha (0.05). Thus the hypothesis proposed was accepted. This means that recruitment has a significant effect on the commitment of managers. 
b. Training. It was obtained that $t$ value $(1,225)<t$ table $(2,052)$ or $\operatorname{Sig}(0.231)>$ alpha (0.05). Thus the hypothesis proposed was rejected, meaning that the training had no significant effect on the commitment of managers.

Table 11. Stage 2 Partial Test Results (t Test)

Sour

Coefficients $^{\mathrm{a}}$

ce:

Rese

arch

Resu

lt in,

2020

\begin{tabular}{llccccc}
\hline & \multicolumn{2}{c}{ Unstandardized Coefficients } & Standardized Coefficients & & \\
\cline { 2 - 5 } Model & B & Std. Error & Beta & T & Sig. \\
\hline 1 & (Constant) & 3.414 & 1.835 & & 1.860 & .073 \\
& Commitment & .856 & .330 & .440 & 2.596 & .015 \\
\hline
\end{tabular}

a. Dependent Variable: Performance

Fro

$\mathrm{m}$ Table 7, it can be known the stage 2 of regression equation which is as follows:

$\mathrm{Y}_{2}=\mathrm{a}+\mathrm{bY}_{1}+\mathrm{e}$

$\mathrm{Y}_{2}=1+440 \mathrm{Y}_{1}+\mathrm{e}_{2}$

$\mathrm{e}_{2}=\sqrt{1-R^{2}}=\sqrt{1-0,194^{2}}=0,962$

The meaning of the equation above is the commitment variable stage coefficient is 0.440 . This means that each increase in perception of commitment by one unit will increase competitive advantage by 0.440 units and vice versa, with fixed assumptions.Then from Table 7, partial test results are obtained by looking at $\mathrm{t}$ arithmetic while the value of $\mathrm{t}$ table at a significance level of 5\% (2-tailed) is obtained by the equation $\mathrm{k}-1$; alpha / $2=30-1 ; 0.05 / 2=$ $28 ; 0.025=2.054$, where $\mathrm{n}$ is the number of samples, $\mathrm{k}$ is the number of independent variables and 1 is constant. Thus, it is known that $t$ arithmetic $(2,596)>t$ table $(2,052)$ or Sig. $(0.015)$ $<$ alpha (0.05).

From the results of the above calculation, the analysis of the stages can be made as follows:

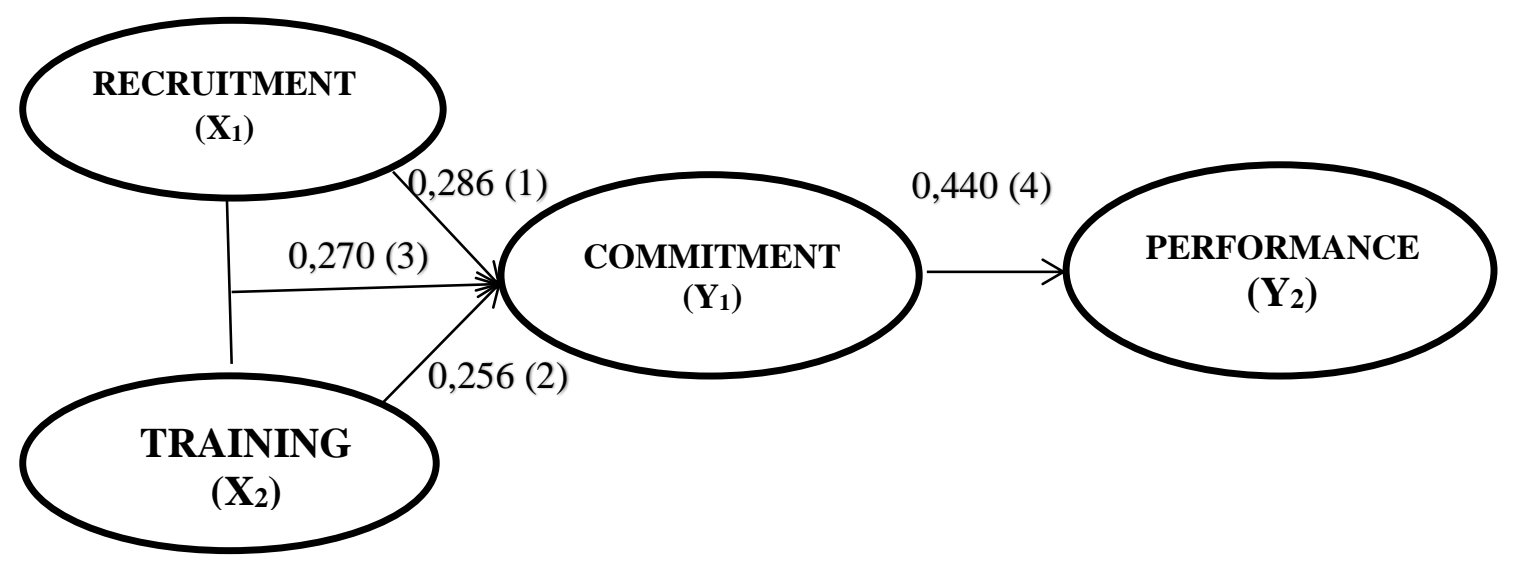

Source: Research Result in, 2020

Figure 2. The Analysis of the stages

\section{DISCUSSION}

\section{The Effect of Recruitment on Manager Commitments}

From the results of this study, it is known that recruitment has a significant influence on the commitment of Village Bussiness Entity managersin Kampar Regency. The coefficient value is positive, which means that the better the recruitment process, the commitment from the manager itself will also increase. In this case, Village Bussiness Entity actually has a basis and conditions in the selection of Village Bussiness Entity managers, but in its implementation Village Bussiness Entit has not been able to carry out the recruitment process properly. This is 
due to the lack of understanding of the importance of the existing laws and regulations in the selection of Village Bussiness Entity managers.

\section{The Effect of Training on Manager Commitment}

From the results of this study, it is known that training does not significantly influence the commitment of Village Bussiness Entity managers. The coefficient value is positive, meaning that the more often the training is held, the commitment from the Village Bussiness Entity manager will increase, but the effect is not significant. In this case it is said that Village Bussiness Entity already has a basis in conducting training, but in carrying out its training, the training aimed is not in accordance with the needs and potentials of the village community, causing many to attend the training only because it is compulsory, not based on their talents or competencies.

\section{The Effect of Recruitment and Training on Manager Commitment}

The results of this study prove that the recruitment and training together have a significant effect on the commitment of Village Bussiness Entity managers in Kampar Regency. Coefficient values are positive. This value indicates that if the recruitment and training are carried out properly, then the commitment of the manager will also increase. In this case Village Bussiness Entity needs to do a recruitment flow that uses the basis in accordance with applicable laws, so that those chosen as managers are those who truly comply with the criteria described in the law. In addition Village Bussiness Entity is also advised to organize training in accordance with the competencies, abilities and potential possessed by the manager and the needs. Therefore, in carrying out its duties and responsibilities, it can be completed effectively and efficiently.

\section{The Effect of Commitment on Manager Performance}

The results of this test indicate that commitment has a significant effect on the performance of Village Bussiness Entity managers. The coefficient value is positive, so it is concluded that the higher the commitment of the Village Bussiness Entity manager, the better the performance will be. With a high commitment from all Village Bussiness Entity managers to carry out their duties properly, it will bring success where Village Bussiness Entity can have significant progress and develop as expected by the government. The variable indicator of high commitment is the statement of desire to manage Village Bussiness Entity continuously, while the lowest is commitment in managing Village Bussiness Entity at the end of the work period. With this it can be concluded that the managers are a little hesitant to continue their responsibilities in Village Bussiness Entity until the end of the work period. This can be caused by the managers feel that they are not suitable for the responsibilities given so that they make them a bit bored and opt out before retirement.

\section{CONCLUSION}

Based on the results of research that has been done, then some conclusions can be drawn as follows:

Recruitment has a significant effect on commitment. Village Bussiness Entity already has a basis and conditions in the selection of Village Bussiness Entity managers, but in its implementation, Village Bussiness Entity has not been able to carry out the recruitment process properly

Training has no significant effect on commitment. The training has not been able to produce a fundamental aspect change, namely improving the quality of its human resources which cannot be demonstrated by BUMDES managers

Together, recruitment and training have a significant effect on commitment. In this case Village Bussiness Entity already has a clear basis, but in its implementation Village Bussiness Entity is still unable to carry out recruitment and implementation as well as training its managers. 
Commitment has a significant effect on performance. But in reality the commitment of Village Bussiness Entity managers is still lacking so that in carrying out its responsibilities it is still considered lacking.

\section{SUGGESTION}

From the research results and conclusions that have been explained, the author provides the following suggestions:

Recruitment must have a clear basis where this can be seen from a number of criteria sought, such as age, educational background, experience, and gender.

The implementation of the training should be oriented to the needs that exist within the Village Bussiness Entity and be carried out in accordance with the competencies of each manager

The recruitment and training process should be carried out in harmony and together, so that managers can know which is capable and in accordance with the criteria required by Village Bussiness Entity

To improve the performance of its human resources, Village Bussiness Entity managers are expected to be able to be more cooperative by listening to the problems faced by stakeholders and able to provide appropriate solutions to the problems faced. This certainly will be very much in touch with the issue of participation and empathy for the village bumdes managers. Stakeholders also expect accountable and transparent financial management.

\section{References}

Ariyanti, Y. (2018). Pengaruh Proses Rekrutmen,Seleksi,dan Motivasi Kerja terhadap Komitmen Organisasi PT. Advantage SCM Batam. Jurnal Administrasi Bisnis, (2 )1, 1-5.

Bangun, W. (2012). Manajemen Sumber Daya Manusia. Jakarta: Erlangga.

Gibson. J., Ivancevich, J., \& Donelly, J. (2014). Organizations: Behavior, Structure, Processes. 14th Edition. New York: The McGraw-Hill Companies, Inc.

Harun, B., \& Herlina, R. (2017). Pemberdayaan masyarakat melalui Peningkatan Pengelolaan Badan Usaha Milik Desa ( BUMDes) Di Desa Gentuma Kecamatan Gentuma Raya Kabupaten Gorontalo Utara provinsi. JOM FISIP (4)2, 1-2.

Hasibuan, S. (2010). Manajemen Sumber Daya Manusia. Jakarta: PT. Bumi Aksara.

Jatmiko, E.D. (2015). Pengaruh Motivasi Kerja dan Komitmen Organisasional terhadap Kinerja Karyawan (Studi Pada Karyawan Kompartemen Pabrik II PT.PETROKIMIA GRESIK. Jurnal Administrasi Bisnis, (21)1, 1-5.

Mangkunegara, A. P. (2012). Manajemen Sumber Daya Manusia. Bandung: PT.Remaja Rosdakarya.

Indrayanto, E.N. (2012). Pengaruh Kepemimpinan,Budaya Organisasi Terhadap Kinerja Karyawan Melalui Komitmen Pada Badan usaha Milik Desa Di Kabupaten Kampar. Jurnal Tepak Manajemen Bisnis, (2)3, 1-3.

Rivai. (2014). Kepemimpinan dan Perilaku Organisasi. Jakarta: PT. Raja Grafindo Persada.

Slamet, F. (2013). Dasar-Dasar Kewirausahaan. Jakarta: Indeks.

Sopiah. (2008). Perilaku Organisasi. Jakarta: Andi.

Robbins, S. (2015). Perilaku Organisasi. Penerbit Salemba Empat. Jakarta.

Verra, N. (2013). Pengaruh Pendidikan dan Pelatihan Terhadap Peningkatan Kinerja Karyawan Pada Balai Pelatihan Teknis Pertanian Kalasey. Jurnal Emba, (1)3, 14. 
Widodo. (2015). Manajemen Pengembangan Sumber Daya Manusia. Yogyakarta: Pustaka Pelajar.

Departemen Pendidikan Nasional Pusat Kajian Dinamika Sistem Pembangunan FE UB. (2007). Buku Panduan Pendirian dan Pengelolaan Badan Usaha Milik Desa. Malang: PP RPDN

Peraturan Pemerintah Kabupaten Kampar Nomor 14 tahun 2007 tentang Pembentukan Badan Usaha Milik Desa Kabupaten Kampar

Peraturan Menteri Desa Nomor 2 tahun 2015 Pembangunan Daerah Tertinggal dan Transmigrasi Indonesia tentang Pedoman tata tertib dan Mekanisme pengambilan Keputusan Musyawarah Desa

Peraturan Menteri Desa Pembangunan Daerah Tertinggal dan Transmigrasi Indonesia Nomor 4 tahun 2015 tentang pendirian, Pengurusan, Pengelolaan,dan pembubaran Badan usaha Milik Desa

Peraturan Menteri Dalam Negeri Nomor 39 Tahun 2010 Tentang Badan Usaha Milik Desa pasal (5),tentang syarat-syarat pembentukan BUMDES. 